\title{
Research Article: Effect of plant geometry on light interception and weed density in cotton under rainfed vertisols
}

\author{
S. ARUNVENKATESH, K. RAJENDRAN AND R. BASKARAN
}

Article Chronicle :

SUMMARY : Field experiments were conducted to study the influence of high density planting system Received :

11.07.2017;

Accepted :

24.07.2017

KeY Words:

High density

planting system,

Weed density, Light

interception in cotton genotypes on the growth and yield and its influence on light interception and weed densityduring winter season of 2011-12 and 2012-13. The experiments were laid out in strip plot design and replicated thrice with four cotton genotypes viz., SVPR 3, Anjali, Suraj and LH 900 and four spacings viz., $30 \times 30 \mathrm{~cm}, 45 \times 30 \mathrm{~cm}, 60 \times 30 \mathrm{~cm}$ and $90 \times 30 \mathrm{~cm}$. In the experimental field, broad leaved weeds were the dominant weeds followed by sedges and grasses. In the year 2011-12 and 2012-13, the weed species of Cynodandactylon, Panicumrepens, Rotoboliacochinsinensis among grasses. Cyperusrotundus was the only sedge weed found in the experimental site. Trianthemaportulacastrum, Partheniumhysterophorus, Digeraarvensis,Amaranthusviridis, Corchorusolitorius and Euphorbia hirta were predominant broad leaved weeds flora found in experimental field. The weed density and their dry matter production were lower at closer plant spacing of $30 \times 30 \mathrm{~cm}$ and $45 \times 30 \mathrm{~cm}$. From this study, it could be concluded and recommended that Anjali variety adopted with a closer plant spacing of $30 \times 30 \mathrm{~cm}$ for higher seed cotton yield and profitability in rainfed condition.

How to cite this article : Arunvenkatesh, S., Rajendran, K. and Baskaran, R. (2017). Effect of plant geometry on light interception and weed density in cotton under rainfed vertisols. Agric.Update, 12(TECHSEAR-2) : 421425; DOI: 10.15740/HAS/AU/12.TECHSEAR(2)2017/421-425. 